\title{
PENGARUH PENGGUNAAN GULA MERAH DALAM AIR MINUM TERHADAP PRODUKSI TERNAK BURUNG PUYUH
}

\author{
THE EFFECTS of USING BROWN SUGAR IN DRINKING WATER ON QUAILS \\ PRODUCTION. \\ oleh \\ Lily Joris $^{1)}$, Shirley Fredriksz ${ }^{2)}$ \\ ${ }^{1,2}$ Jurusan Peternakan Fakultas Pertanian Universitas Pattimura \\ Jl. Ir. M. Putuhena, kampus Poka Ambon 97233 \\ Email: lilyjoris49@gmail.com dan shirleyfredriksz90@gmail.com)

\begin{tabular}{l|l} 
Diterima: 22 April 2020 & Disetujui: 3 Juni 2020
\end{tabular}

\begin{abstract}
Abstrak
Tujuan dalam penelitian ini adalah untuk mengetahui Penggunaan gula merah untuk memperbaiki komposisi zat gizi karena perbedaan komposisi gizi dari pakan yang digunakan dibandingkan kebutuhan puyuh. Penelitian ini dilakukan di Kota Ambon selama satu bulan yang berlangsung sejak Januari sampai Februari 2020. Bahan yang digunakan dalam penelitian ini adalah: 75 ekor ternak puyuh berumur 5 bulan yang dibagi dalam 3 kelompok, pakan ayam petelur Par L dan gula merah. Variabel yang diukur dalam penelitian ini adalah : konsumsi ransum, konsumsi air, jumlah/produksi telur dan berat telur. Rancangan yang digunakan adalah rancangan acak lengkap (RAL). Hasil penelitian konsumsi pakan ternak puyuh dengan penambahan gula merah dalam air minum menunjukkan bahwa perlakuan tanpa penambahan gula merah dalam air minum (Kontrol P0) tidak menunjukkan perbedaan nyata terhadap perlakuan penambahan gula merah $1 \%$ (P1) dan $2 \%(\mathrm{P} 2)$, pelakuan penambahan gula merah $1 \%(\mathrm{P} 1)$ menunjukan perbedaan yang nyata terhadap pengunaan gula merah $2 \%(\mathrm{P} 2)$. Sedangkan konsumsi air, produksi telur dan berat telur tidak terlihat perbedaan antar perlakuan yang dicobakan.
\end{abstract}

Kata kunci : Puyuh, gula merah, pakan, produksi

\begin{abstract}
The purpose of this research isthe use of brown sugar in the research is done in order to fix the composition of the nutrition due to the difference of nutrition in the feed and the one required by the quails. This research is done in Ambon for the period of one month that were carried in January until February 2020. The components that used in this research are: 75 Quails with 5 months of age that are divided into 3 flocks, Eggs Producing Chicken Feed Par L, and Brown Sugar.The variables that are measured in this research are: feed consumption, water consumption, number of produced eggs, and the weight of the eggs. The design that is used for this research is a Completely Randomized Design. The result of this research in regards to adding brown sugar in quails drinking water shows that: the treatment without adding brown sugar in the water (Control P0) did not shows any real difference with adding $1 \%$ of brown sugar to the water (P1) and adding $2 \%$ of brown sugar to the water (P2). The adding of $1 \%$ of brown sugar to the water (P1) shows a significant difference with adding $2 \%$ of brown sugar to the water (P2). Furthermore, water consumption, eggs production, and the weight of produced eggs does not show any difference between all of the tested treatments.
\end{abstract}

Keywords: Quail, brown sugar, feed, production 


\section{PENDAHULUAN}

Burung puyuh (cortunis cortunis japonica) merupakan salah satu jenis ternak unggas yang dapat membantu kegiatan perekonomian masyarakat peternakan karena dapat menyumbang pertumbuhan ekonomi, penghasil pangan sumber protein hewani dan memanfaatan lahan sempit serta penyeimbang ekosistem lingkungan. Penyebaran ternak burung puyuh berdasarkan statistik pertanian 2013 terdapat pada 24 propinsi dimana Propinsi Maluku bukan merupakan salah satu daerah sentra pengembangan, meskipun demikian kebutuhan dan konsumsi produk puyuh baik daging maupun telur tetap berlangsung pada masyrakat.

Keunggulan dari usaha beternak burung puyuh antara lain : 1) merupakan salah satu bidang usaha yang dapat diterima dan dikembangkan masyarakat; 2) tidak membutuhkan modal usaha yang besar untuk memulai usaha ini, perputaran modal cepat dan mudah; 3) telur dan daging burung puyuh bergizi tinggi, serta cepat berproduksi; 4) tidak membutuhkan tempat yang luas untuk usaha; 5) dapat menciptakan lapangan kerja baru ( Rukmana dan Yudirachman, 2017). Selain itu kelebihan dari beternak burung puyuh menurut Lestari (2019) adalah 1) waktu usaha yang pendek; 2) bisa dipelihara dalam skala rumah tangga; 3) resisten terhadap penyakit; 4). banyak panen tambahan selain telur yaitu daging afkir, kotoran dan bulu .

Pakan merupakan memegang peranan penting yang perlu diperhatikan dalam usaha peternakan termasuk usaha ternak burung puyuh, karena kurang lebih $70 \%$ dari biaya produksi adalah biaya pakan. Tatalaksana pemberian pakan berpengaruh terhadap produktivitas puyuh, jika pakan tidak dikelola dengan baik seperti kualitas nutrisi yang tidak memadai akan menyebabkan produksi tidak optimal.

Masalah pakan puyuh terutama puyuh petelur harus memenuhi kebutuhan zat gizi baik kualitas maupun kuantitasnya sehingga pengaruhnya nyata terhadap produksi telur.
Keunggulan lain dari burung puyuh adalah mampu berproduksi pada usia muda, siklus reproduksinya singkat, tidak membutuhkan modal yang besar untuk usaha, mudah pemeliharaannya, serta dapat dipelihara dalam jumlah besar dengan tempat yang terbatas, memiliki laju produksi telur yang tinggi namun rendah konsumsi pakannya (Lokapitasari, 2017).

Penggunaan gula merah dalam penelitian untuk memperbaiki komposisi zat gizi karena perbedaan komposisi gizi dari pakan yang digunakan dibandingkan kebutuhan puyuh. Air gula merah bukanlah merupakan sumber energy utama, jadi pemberian larutan gula merah sifatnya hanyalah sebagai nutrisi tambahan, sedangkan untuk sumber energy utama tetaplah menggunakan ransum yang tepat agar mendapatkan hasil yang terbaik (Pratama, 2018). Kandungan gizi gula merah per $100 \mathrm{~g}$ : $386 \mathrm{kka}$, Protein : 3,0 g, Karbohidrat : 74,08 g, Lemak : $10 \mathrm{~g}$, Kalsium : 76,06 mg, Fosfor : $37 \mathrm{mg}$, Zat besi : $37 \mathrm{mg}$, dan yang lainnya. Dalam opini masyarakat terkait pemanfaatan bagi ternak puyuh dikatakan bahwa efek pemberian gula pasir hasilnya negative tetapi pemberian gula merah memberikan hasil yang positif, berarti memberi hasil yang baik bagi pertumbuhan ternak ( anonym, 2011). Penambahan gula merah dalam air minum baik untuk meningkatkan kebutuhan tubuh unggas karena memiliki antioksidan yang tinggi (Anonym,2018).

Berdasarkan kenyataan ini maka telah dilakukan penelitian untuk mengetahui produktivitas burung puyuh dengan menggunakan pakan ayam petelur dengan penambahan gula merah dalam air minum mengingat sarana produksi puyuh seperti pakan tidak tersedia di daerah ini. Tujuan penelitian ini adalah untuk mengetahui bagaimana produksi ternak burung puyuh yang diberi pakan ternak ayam petelur dengan penambahan air gula untuk memenuhi kebutuhan gizinya. Kegunaan penelitian ini 1. sebagai bahan banding dalam pemanfaatan pakan ayam petelur jika ingin beternak puyuh pada daerah bukan 
sentra pengembangan dan produksi ternak burung puyuh. 2. Sebagai sumber informasi pemanfaatan gula merah dalam air minum

\section{METODE PENELITIAN}

Penelitian ini dilakukan di Kota Ambon selama satu bulan yang berlangsung sejak Januari sampai Februari 2020. Bahan yang digunakan dalam penelitian ini adalah: 75 ekor ternak puyuh berumur 5 bulan yang dibagi dalam 3 kelompok, pakan ayam petelur Par L dan gula merah. Pakan petelur yang digunakan merupakan produksi Comfeed dengan komposisi nutrisi sebagai berikut: kandungan air $12 \%$, protein 17 $\%$, lemak 3\%, serat kasar 6\%, abu $14 \%$. Peralatan yang digunakan selama penelitian adalah kandang puyuh, tempat pakan dan minum, timbangan digital untuk menimbang pakan, telur dan gula merah, gelas ukur untuk mengukur air minum, grinder untuk menghaluskan pakan, termometer ruang dan peralatan penunjang lainnya. Perlakuan yang dilakukan adalah dengan menggunakan gula merah sebanyak $1 \%$ dan $2 \%$ dalam air minum sehingga perlakuan yang dilakukan adalah :

$\mathrm{P} 0=$ Perlakuan tanpa penambahan gula

merah dalam air minum (kontrol) terhadap produksi burung puyuh baik jumlah dan berat telur.

$\mathrm{P} 1=$ Perlakuan penambahan gula merah

$1 \%$ dalam air minum

$\mathrm{P} 2=$ Perlakuan penambahan gula merah

$2 \%$ dalam air minum

Variable yang diukur dalam penelitian ini adalah

: konsumsi ransum, konsumsi air, jumlah/produksi telur dan berat telur. Rancangan yang digunakan adalah Rancangan Acak lengkap (RAL) dengan model statistik :

$$
Y i j=\mu+\alpha i+\varepsilon i j
$$

Dimana :

Yij = nilai pengamatan utuk perlakuan

ke-i pada ulangan ke $\mathrm{j}$

$\mu=$ rataan umum

$\alpha \mathrm{i}=$ pengaruh perlakuan ke $\mathrm{i}$

$\varepsilon i j=$ galat percobaan dari perlakuan ke-i pada ulangan $\mathrm{ke} \mathrm{j}$

Hasil penelitian ini akan diolah menggunakan analisa SPSS 16

\section{HASIL DAN PEMBAHASAN}

\section{Hasil Penelitian}

\begin{tabular}{lccc}
\hline \multirow{1}{*}{ Keterangan } & \multicolumn{3}{c}{ Perlakuan } \\
\cline { 2 - 4 } & $\mathrm{P} 0$ & $\mathrm{P} 1$ & $\mathrm{P} 2$ \\
\hline Konsumsi Pakan & $23,1480^{\mathrm{ab}}$ & $23,8560^{\mathrm{b}}$ & $22,1190^{\mathrm{a}}$ \\
Konsumsi Air Minum & $72,7011^{\mathrm{a}}$ & $76,9841^{\mathrm{a}}$ & $68,6005^{\mathrm{a}}$ \\
Produksi Telur & $22(87,6122 \%)^{\mathrm{a}}$ & $23(92,1154 \%)^{\mathrm{a}}$ & $23(91,7308 \%)^{\mathrm{a}}$ \\
Berat Telur & $11,387^{\mathrm{a}}$ & $13,186^{\mathrm{a}}$ & $11,155^{\mathrm{a}}$ \\
\hline Ket
\end{tabular}

Ket : superscript yang berbeda menunjukkan perbedaan yg signifikan $(\mathrm{P}<0,05)$

\section{Pembahasan}

\section{Konsumsi Pakan}

Pakan ternak puyuh petelur sebaiknya tercukupi baik secara kualitatif maupun kuantitatif, karena sangat berpengaruh pada produksi telur. Hasil penelitian konsumsi pakan ternak puyuh dengan penambahan gula merah dalam air minum menunjukan bahwa perlakuan tanpa penambahan gula merah dalam air minum (Kontrol P0) tidak 
menunjukkan perbedaan nyata terhadap perlakuan penambahan gula merah $1 \%(\mathrm{P} 1)$ dan $2 \%$ (P2), pelakuan penambahan gula merah $1 \%(\mathrm{P} 1)$ menunjukan perbedaan yang nyata terhadap pengunaan gula merah $2 \%$ (P2). Perbedaan ini disebabkan oleh kandungan energi yang terdapat dalam air minum yang mengandung lebih banyak gula merah. Unggas akan makan untuk memenuhi kandungan energi, jika sudah terpenuhi maka konsumsi ransum dihentikan. Pada perlakuan P2 penambahan gula merah sebanyak $2 \%$ menyumbang lebih banyak energy karena komposisi gula merah terdiri dari $77-84,31 \%$ karbohidrat (sukrosa) yang merupakan sumber energi (SNI 013743 1985; BPT Banten 1995). Gula merah selain meningkatkan stamina dan daya tahan tubuh juga merupakan sumber energi tambahan, karena sumber energi utama berasal dari pakan yang dikonsumsi (Pratama, 2018).

Konsumsi pakan puyuh periode layer per ekor per hari sebesar 20 - 22 gram ( Rukmana dan Yudirachman, 2017). Konsumsi pakan dalam penelitian ini lebih besar dari yang dianjurkan yaitu sebesar 23,1480 (P0); $23,8560^{\mathrm{b}}$ (P1) dan 22,1190 (P2). Hal ini disebabkan karena pakan yang diberikan merupakan $100 \%$ pakan ayam petelur dengan kandungan energi rendah. Komposisi pakan

\section{Konsumsi Air Minum}

Air minum vital bagi ternak puyuh terutama yang dikandangkan. Jika dikandangkan air minum harus tersedia terus menerus (ad libitum). Pemberian yang baik adalah 2 - 3 kali/hari. Kebutuhan air ternak puyuh umur 36 - 42 minggu sebesar 54 ml/ekor/hari (Marsudi; 2012 dalam Wicaksono Sigit, 2018) .

Rata-rata kebutuhan air minum untuk ternak puyuh sebesar 50-60 $\mathrm{ml} / \mathrm{ekor} / \mathrm{hari}$ ( Rukmana dan Yudirachman, 2017). Hasil penelitian menunjukan bahwa rata-rata konsumsi air minum sebesar 68,6005 $\mathrm{ml} /$ ekor/hari (P2); 76,9841ml/ekor/hari (P1) dan $72,7011 \mathrm{ml} /$ ekor/hari (P0) ini lebih tinggi dari ternak ayam petelur dan puyuh petelur agak berbeda dimana pakan ayam petelur mengandung $2650 \mathrm{kkal}$ energy/100 gram ( Ketaren 2010), sedangkan puyuh membutuhkan $2700 \mathrm{KKal}$ energy/100 gram ransum. Puyuh yang diberikan pakan rendah nutrisi, akan meningkatkan jumlah konsumsinya. Pakan yang mengandung $3000 \mathrm{kkal} / \mathrm{kg}$ pakan menunjukan konsumsi pakan yang lebih rendah dari pada puyuh yang diberikan pakan dengan kandungan energi 2600 dan 2800kkal $/ \mathrm{kg}$ pakan. Attatia et al.(,2006) dalam Lokapitasari (2017). Konsumsi pakan yang tinggi sebagai akibat pemberian energi pakan yang rendah merupakan kompensasi untuk pemenuhan kebutuhan energinya. Slamet ( 2014) menyatakan bahwa kebutuhan pakan burung puyuh umur 42 minggu sampai afkir adalah sebesar 22,77 gram/ekor/hari dan harus tersedia terus menerus dalam jumlah yang cukup.

Pemberian pakan ayam petelur pada penelitian ini disebabkan karena tidak tersedia pakan puyuh didaearah penelitian. Hasil penelitian ini dapat dijadikan pertimbangan pemeliharaan ternak puyuh pada daerah bukan sentra produksi burung puyuh karena ketidak tersediaan pakan khusus ternak puyuh.

yang dianjurkan. Hal ini disebabkan karena suhu selama penelitian sangat tinggi berkisar antara $26-34{ }^{\circ} \mathrm{C}$. Suhu ideal untuk hidup normal ternak puyuh adalah $20-25{ }^{\circ} \mathrm{C}$ (Agromedia,2018). Konsumsi air pada penelitian ini tidak menunjukkan perbedaan antar perlakuan. Meskipun demikian secara numerik terdapat perbedaan jumlah konsumsi air dimana perlakuan penambahan $2 \%$ gula merah ( P2) lebih rendah dari perlakuan lain karena lebih manis dan kental terlihat secara fisik.

Jika dibandingkan dengan penelitian Sudrajat dkk., (2015) dengan menggunakan daun sirih dalam air minum (20ml/1liter air) dibandingkan dengan air minum ditambahkan 
antibiotik komersial diperoleh besaran konsumsi air sebesar 40,98-46,25ml/ekor dan $59,37-62,10 \mathrm{ml} /$ ekor terlihat bahwa terjadi penurunan konsumsi air pada perlakuan

\section{Produksi Telur}

Produksi telur merupakan salah satu tolok ukur penting pada peternakan puyuh. Jika aktivitas metabolisme hidup pokok sudah terpenuhi maka nutisi yang ada digunakan untuk produksi telur. Beberapa faktor dapat mempengaruhi produksi telur, antara lain adalah pakan. Secara garis besar produksi telur puyuh dipengaruhi oleh beberapa faktor, antara lain genetik dan faktor luar seperti pakan, kandang, temperatur, lingkungan, penyakit dan stress (Yasin, 1988). Rata - rata produksi telur puyuh selama satu tahun adalah $300-310$ butir/ekor/tahun atau 25 - 26 butir/ekor/bulan ( Rukmana dan yudirachman, 2017). Burung puyuh betina dapat berproduksi antara 200-300 butir setiap tahun. Dengan berat telurr sekitar $10 \mathrm{~g} /$ butir atau $7 \%-8 \%$ dari berat badan (Nugroho dan Mayun 1986).

Hasil penelitian menunjukan bahwa produksi telur rata-rata selama satu bulan penelitian sebanyak 22 - 23 butir/ekor/bulan atau sebesar $87,61 \%-92,11 \%$. Hasil penelitian tidak

\section{Berat Telur}

Hasil penelitian rata - rata berat telur selama penelitian tidak menunjukkan perbedaan yang nyata antar perlakuan. Rata - rata berat telur sebesar 11,38 (P0), 13,18 (P1) dan 11,15 (P3) gram /butir. Berat telur ini sama dengan yang direkomendasikan Rukmana dan Yudirachman, (2017) sebesar 11-13 gram/butir. Hal ini menunjukan bahwa meskipun mengkonsumsi pakan ternak ayam petelur, puyuh mampu memproduksi telur sesuai produktivitasnya. Keadaan ini memberi peluang untuk mengusahakan ternak puyuh walaupun tidak tersedia pakan yang dibutuhkan. Ketidaktersediaan pakan ini disebabkan karena tidak semua daerah di Indonesia merupakan penambahan daun sirih dibandingkan air minum biasa. Hal ini terbukti dalam penelitian bahwa semakin tinggi konsentrasi penambahan gula merah menyebabkan penurunan konsumsi air.

menunjukan perbedaan antar perlakuan. Jika dibandingkan dengan produksi telur puyuh yang normal berarti bahwa produksi telur selama penelitian lebih rendah. Hal ini disebabkan karena konsumsi pakan yang berbeda dimana pakan yang diberikan adalah pakan ayam petelur/par L dengan komposisi zat gizi yang berbeda dengan pakan ternak puyuh. Komposisi gizi pakan puyuh untuk protein sebesar $17 \%$ dengan kandungan energi metabolis sebesar 2700 Kkal ( SNI 01-3907-2006) sedangkan pakan ayam petelur dengan komposisi protein $15 \%$ dengan kandungan energi sebesar 2600 Kkal. (SNI 01-3928- 2600) Pengaruh penggunaan gula merah dalam air minum pada tidak memberikan pengaruh terhadap produksi telur puyuh, meskipun demikian hasil ini lebih tinggi dari penelitian Lutfhi dkk ( 2015) yang menunjukkan bahwa produksi telur puyuh berkisar antara 58,3 \% $-70,31 \%$,pada penelitian pengaruh penambahan larutan ekstrak kunyit (curcuma domestica) dalam air minum terhadap produksi telur.

daerah potensial pengembangan ternak puyuh. Hasil penelitian ini menunjukan bahwa penggunaan air gula merah 1 dan 2 persen dalam air minum memberikan dampak berat telur yang sama dengan puyuh yang diberi pakan komersial khusus puyuh.ian berat telur

Hasil penelit berat telur tidak berbeda dengan hasil penelitian Fithria Nisa Hanifah dkk (2019) sebesar 10,22-10,65 dengan pemberian Substitusi Black Soldier Fly Larvae (BSFL) pada pakan komersial. Hal ini disebabkan karena protein yang cukup dalam pakan (minimal 17\% berdasarkan SNI 01-39052006) dapat memenuhi kebutuhan organ reproduksi burung puyuh, sehingga dapat bersiklus lebih baik dan tepat waktu dan mampu memberi keuntungan bagi peternak 
Hasil penelitian ini lebih tinggi dari rekomendasi life style kompas sebesar 10 -12 gram/butir, dengan nilai gizi 3-4 kali lebih tinggi dibandingkan telur ayam dengan berat $50-70$ gram/butir (Listiyowati dan rospitasari 2007 dalam Lokapitasari (2017) melaporkan bahwa puyuh bertelur dalam satu tahun sebanyak 130300 butir dengan berat rata-rata 10 gram.

Manfaat lain yang bisa didapat dari satu butir telur puyuh adalah telur puyuh dapat dimakan mentah, mengandung 13 persen protein dibandingkan telur ayam hanya 11 persen. Selain itu, telur puyuh mengandung $140 \mathrm{m \mu}-\mathrm{g}$ vitamin $\mathrm{B} 1$, bandingkan dengan $50 \mathrm{m \mu}-\mathrm{g}$ yang ada di telur ayam. Kandungan vitamin A dan B2 telur puyuh dua kali telur ayam. Telur puyuh

\section{KESIMPULAN}

Berdasarkan hasil penelitian dapat disimpulkan bahwa penambahan gula merah dalam air minum sebesar 1 dan 2 persen dengan pemberian pakan ternak ayam petelur pada

\section{DAFTAR PUSTAKA}

Agromedia 2018. Syarat Kandang Dan Bibit Yang Baik Bagi Puyuh . https Agromedia. net jendela komunitas pertanian Akses 12/7/20

Agromedia b ,2018 . Sepuluh Alasan Mengapa Bisnis Ternak Puyuh Menguntungkan. https://Agromedianet.

Anonym $^{\text {a }}$,2011.https://lifestyle.kompas.com/rea d/2011/06/03/13385556/Telur.Puyuh.S i.Mungil sakti.

Anonym. b 2011. Puyuh Jaya . Opini Efek Pemberian Gula Pasir. Wordpress.com $2011 \mathrm{di}$ akses juli 2020. https://puyuhjaya.wordpress.com/tag/ef ek-negatif/

Anonym, 2018. www.dunia unggas. Com/ 2018/05/07.vitamin untuk unggas pada cuaca panas

BPTP Banten 2005. Kajian Sosial Ekonomi Aren di Banten.Balai Pengkajian memiliki zat besi dan potasium lima kali lebih banyak daripada telur ayam. Karena kandungan tersebut, telur puyuh masuk dalam kategori dietary food. Telur puyuh tidak memiliki kolesterol jahat (LDL) sebaliknya sangat kaya dengan kolesterol baik (HDL). Telur puyuh tidak menyebabkan alergi sebaliknya telur puyuh bisa membantu mengatasi gejala alergi karena memiliki protein ovomucoid, yang dipakai untuk produksi obat antialergi. Telur puyuh dapat dikonsumsi mentah setelah telur tersebut dicuci dalam air panas. Tidak perlu khawatir tentang adanya Salmonella karena suhu tubuh burung puyuh lebih tinggi dari pada ayam sehingga Salmonella tidak dapat hidup (anonym, 2011).

burung puyuh tidak memberikan pengaruh yang berbeda terhadap konsumsi air, produksi dan berat telur namun pemberian air gula merah 2 persen memberikan pengaruh terhadap konsumsi pakan.

Teknologi Pertanian Banten. http://banten.litbang.pertaniangoid

Fithria N.H, S. Koesnoto, Soeharsono, A. Al Arif., W P. Lokapirnasari, N. Harijani, Siti Hadijah dan M. R Th. Hutabarat .,2019., Performa Produksi dan Analisis Usaha Puyuh (Coturnix coturnix japonica) yang Diberi Substitusi Black Soldier Fly Larvae (BSFL) pada Pakan Komersil., jurnal Sain Veteriner, Vol. 37. No. 2. Desember 2019, Hal. 219-226 DOI: 10.22146/jsv.

49067 ISSN 0126-0421 (Print), ISSN 24073733 (Online) Tersedia online di $\underline{\text { https://jurnal.ugm.ac.id/jsv }}$

Ketaren P.P., 2010. Kebutuhan gizi ternak unggas di Indonesia dalam Wartazoa 20 (4): 172- 180.

Lestari V.E.2019 Cara Budidaya Ternak Burung Puyuh Paling Mudah Untuk Pemul

https://www.cekaja.com/info/carabudidaya-ternak-burung-puyuh/ 
Lokapitasari W.P, 2017. Nutrisi Dan Manajemen Pakan Burung Puyuh. Pusat Penerbitan Dan Percetakan Universitas Airlangga Surabaya.

Luthfi M, Hanafi Nur, dan Anggraeni. 2015. Pengaruh Penambahan Larutan Ekstrak Kunyit dalam Air Minum terhadap Produksi Telur Burung Puyuh. Jurnal Peternakan Nusantara 2(2):159-166. Jurnal Peternakan Nusantara ISSN 2442-2541Volume 1 Nomor 2, Oktober 2015

https://ojs.unida.ac.idjpnu/article/view/ $\underline{230}$

Nugroho dan Mayun .,1986. Mengenal Ternak Burung Puyuh (Coturnix coturnix japonica) | https://sinauternak.com/mengenalburung-puyuh/

Pratama W, 2018 Jurnal budidaya ternak , manfaat penggunaan gula merah pada ternak https://budidaya ternak.id).

Rukmana R dan Yudirachman . 2017. Wirausaha ternak puyuh secara intensif.Lily publisher. Yogyakara..

Slamet ,W. 2014. Beternak dan berbisnis puyuh 3,5 bulan balik modal. http://www.bukabuku.com/browses/pro duct/9789790065062/beternak-

berbisnis- puyuh-35-bulan-balikmodal.html

Sudrajat D., D. Kardaya dan Sahroji,2015., produksi telur burung puyuh yang diberi air minum larutan daun sirih .jurnal peternakan nusantara.ISSN 2412-2514. Vol. 1 No2. Oktober 2015 https:/

ojs.unida.ac.idjpnu/article/view/29 6

Wicaksono dan Kukuh Sigit (2018) pengaruh suplementasi tepung temulawak (curcuma xanthorrhiza) dalam ransum terhadap kinerja burung puyuh jantan. skripsi thesis, universitas mercu buana yogyakarta. pengaruh suplementasi tepung temulawak (curcuma xanthorrhiza) dalam ransum terhadap kinerja burung puyuh jantan - umby repository yhttp://eprints.mercubuanayogya.ac.id/2719/

Wisnu P. 2018.

https://budidayaternak.id/manfaatgula-merah-untuk-ayam Diposting pada 9 Juli 2018 diakses 25/8/2020 